
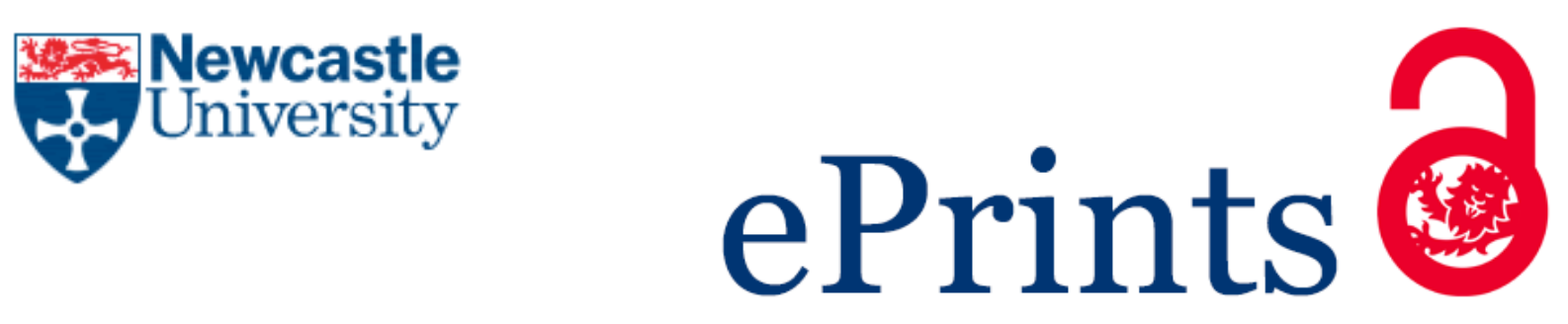

\author{
Sohail M, Khan MN, Qureshi NA, Chaudhry AS. \\ Monitoring DNA Damage in Gills of Freshwater Mussels (Anodonta anatina) \\ Exposed to Heavy Metals. \\ Pakistan Journal of Zoology 2017, 49(1), 321-328
}

\title{
Copyright:
}

All contents of Pakistan Journal of Zoology are Gold Open Access (free for readers and free for authors) under a Creative Commons Attribution-NonCommercial 4.0 International License, which permits unrestricted use, distribution, and reproduction in any medium, provided the original work is properly cited.

DOI link to article:

https://doi.org/10.17582/journal.pjz/2017.49.1.321.328

Date deposited:

$24 / 01 / 2018$

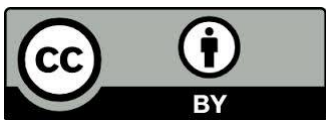

This work is licensed under a Creative Commons Attribution 4.0 International License 


\section{Monitoring DNA Damage in Gills of Freshwater Mussels (Anodonta anatina) Exposed to Heavy Metals}

\author{
Muhammad Sohail ${ }^{1, *}$, Muhammad Naeem Khan ${ }^{1}$, Naureen Aziz Qureshi ${ }^{2}$ and \\ Abdul Shakoor Chaudhry ${ }^{3}$ \\ ${ }^{1}$ Department of Zoology, University of the Punjab, Lahore 54590, Pakistan. \\ ${ }^{2}$ Government College for Women University, Faisalabad, Pakistan. \\ ${ }^{3}$ School of Agriculture, Food and Rural Development, Newcastle University, NE1 \\ $7 R U U K$.
}

\begin{abstract}
A B S T R A C T
Study was carried out to investigate the genotoxic effect of different levels of heavy metals on gill cells of freshwater mussels (Anodonta anatina), a sentinel species in aquatic environment. Freshwater mussels were exposed to none $\left(0 \mu \mathrm{g} \mathrm{L}^{-1}\right)$, low $\left(120 \mu \mathrm{g} \mathrm{L}^{-1}\right)$, medium $\left(240 \mu \mathrm{g} \mathrm{L}^{-1}\right)$ and high $\left(360 \mu \mathrm{g} \mathrm{L}^{-1}\right)$ levels of lead $(\mathrm{Pb})$, chromium $(\mathrm{Cr})$ and copper $(\mathrm{Cu})$ alone and in combinations $(\mathrm{Pb}+\mathrm{Cr}+\mathrm{Cu})$ for 15 days under laboratory conditions. Gill cells of mussels were used to determine the DNA damage by comet assay. The tail DNA (\%), comet tail length and olive tail moment (OTM) were the parameters selected to detect DNA damage. Low doses $\left(120 \mu \mathrm{g} \mathrm{L}^{-1}\right)$ of each metal induced significantly higher levels of DNA strands breaks as compared to medium dose $\left(240 \mu \mathrm{g} \mathrm{L}^{-1}\right)$ and very low levels of DNA damaged was observed at high dose $\left(360 \mu \mathrm{g} \mathrm{L}^{-1}\right) . \mathrm{Cu}$ and $\mathrm{Pb}$ showed significantly higher value of \% of tail DNA $(56.74 \pm 1.81,47.36 \pm 1.23)$ and comet tail length $(41.30 \pm 0.758,49.15 \pm 1.90)$, respectively, as compared to $\mathrm{Cr}$ and combined metal exposure $(\mathrm{Pb}+\mathrm{Cu}+\mathrm{Cr})$. The lowest levels of DNA damage for all the parameters were observed in combined metal treatment. Genotoxic effect of metals on freshwater mussels is very important to assess the aquatic health and could be suggested as biomarker. It is concluded that the $\mathrm{Cu}$ and $\mathrm{Pb}$ induced more DNA damage as compared to $\mathrm{Cr}$ and combined metal exposure $(\mathrm{Pb}+\mathrm{Cu}+\mathrm{Cr})$. Moreover, our results showed that the low dose treatment of metals have more genotoxic effect as compared to the medium and high doses.
\end{abstract}
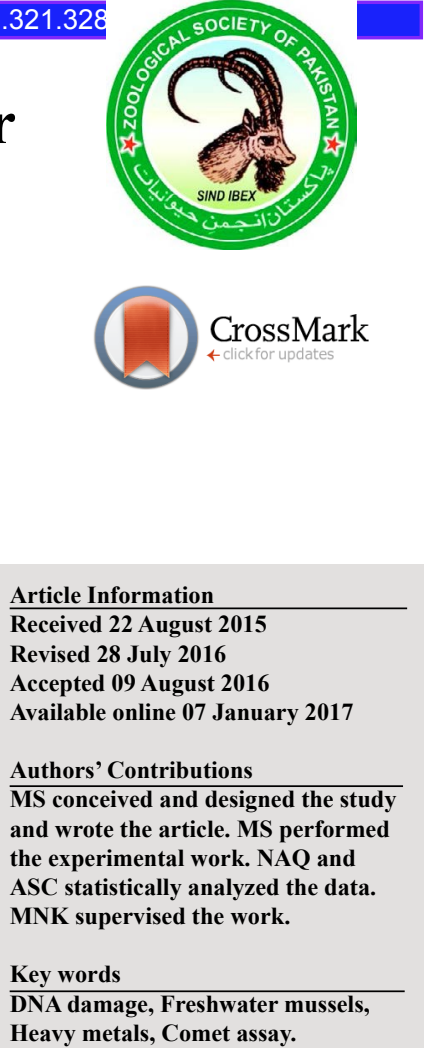

\section{INTRODUCTION}

$\mathrm{F}$ reshwater ecosystems such as lakes and rivers are very essential resources because they contribute in biodiversity, regulation of climate, managing floods and to meet the demands of drinking water (Ra et al., 2011; Hansen, 2012). The biodiversity of freshwater ponds are mainly depends on the variety of free floating organisms such as phytoplankton and zooplankton (Sohail et al., 2014). Unfortunately, freshwater system are continually polluted due to increasing anthropogenic activities such as urbanization, industrialization, agricultural expansion, and manipulation of mineral resources which cause a severe damage especially in less develop countries (Thevenon et al., 2013; Zan et al., 2012). Among the other harms, the risks of toxic metals in freshwater bodies cause adverse effect to the health of ecosystem (UNEP, 2011). The exposure to these metals can also induce harmful effects

\footnotetext{
* Corresponding author: sohail.zoologist@gmail.com 0030-9923/2017/0001-0321 \$ 9.00/0

Copyright 2017 Zoological Society of Pakistan
}

in organisms such as interruption in homeostasis and destruction in their DNA (Tsangaris et al., 2010).

Few of the metals such as copper and zinc are required for metabolic processal though could be lethal at higher concentrations. Some metals prove dangerous even at very minute concentrations (e.g., mercury, cadmium, and lead) and are suggested as harmful metals for aquatic life because of their perseverance as describe by Turkmen et al. (2008). Lead is one of the more common and persistent environmental pollutants. Lead has no valuable function for the living organism and is said to be non-essential metal (Johannesson, 2002). It can also accumulate in the tissues and it interferes with the other bio elements such as $\mathrm{Ca}, \mathrm{Zn}$ and $\mathrm{Cu}$ which cause a variety of serious disorders (Berrahal et al., 2011).

Many invertebrates found in aquatic ecosystem are sensitive to contaminants and could accumulate heavy metals form their surrounding water (Reinecke et al., 2003). Soegianto et al. (1999) reported that the concentration of copper in unpolluted water is less than $5 \mathrm{ppb}$ and it may reach almost about $3 \mathrm{ppm}$ in highly polluted environment (Parry and Pipe, 2004). The constantly increasing 
concentration of copper in aquatic environment is a serious danger to the aquatic organisms. Though, copper is vital for the proper functioning of living organisms. For example, it may be a cofactor for the enzyme action, but high concentration may prove toxic to an organism when exposed chronically to an aquatic environment (Gaetke and Chow, 2003).

The health of aquatic ecosystem has been monitored through the chemical analysis of pollutant level in soft tissues of bivalves (Goldberg, 1986; Cantillo, 1998). As being sessile, mussels are ecologically very important as they can bioaccumulate a broad range of varying type of contaminants from aquatic ecosystems (Kimbrough et al., 2008). Freshwater mussels are good candidates for evaluating the aquatic health as their soft tissues are continuously exposing to ambient water and due to their filter feeding habit they can assess the toxicity even when the level of pollutants are changing slightly (Blackmore and Wang, 2003; Viarengo and Canesi, 1991). Bivalves have huge survival rate, are easy to keep in the laboratory conditions, and are able to bear greater concentrations of variety of pollutants (Sarkar et al., 2008; Zhou et al., 2008).

Freshwater mussels are usually manipulated for determining genotoxicity (Binelli et al., 2010; Rocher et al., 2006; Parolini et al., 2011). The soft tissues such as in muscular foot, mantle, digestive tract and gills are generally used as target organs to determine the aquatic pollution. Due to continuous exposure to water, gill tissue of fresh water mussels is suggested to study pollutants in water (Makala and Oikari, 1990; Stambuk et al., 2008). Many studies have shown that the gill cells are more vulnerable than the haemocytes for the genotoxic related contaminants (Bourgeault et al., 2010; Vincent- Hubert et al., 2011).

It is essential to locate the early warning response at molecular level to protect the aquatic ecosystem from sever damages (Kalpaxis et al., 2004). DNA strand breakage is considered to be one of the primary signals of environmental deterioration (Binelli et al., 2007; Klobucar et al., 2008) and this technique has become well known to evaluate the genotoxic effect of contamination on organismic and population level (Depledge, 1998). Comet assay is a quick method to assess the genotoxicity in aquatic organism due to environmental pollutants (Jha, 2008). This is said to be one of the commonly used methods for contaminant biomonitoring in aquatic animals related to genotoxicity (Chen et al., 2007; Picado et al., 2007).

The aim of this study was to evaluate the effect of trace metals on gills of freshwater mussels with reference to the DNA damage. Secondly, the effect of different doses of various metals on DNA damaging was also investigated in this study.

\section{MATERIALS AND METHODS}

\section{Animal collection and placement}

Freshwater mussels (Anodonta anatina) of average size $(64.5 \pm 2 \mathrm{~g})$ were collected from an unpolluted freshwater pond. The temperature of pond water at the time of collection was approximately $20.5 \pm 1.5^{\circ} \mathrm{C}$. Mussels were directly carried to the fish hatchery in cool plastic bags and placed in large rectangular cemented tanks with filtered pond water. Animals were fed with the green algae collected from the same fish pond and acclimatized for 10 days before used for experimentation. Mussels were kept at $16.8 \pm 1.2^{\circ} \mathrm{C}$ and water was changed daily during acclimatized period.

\section{Experimental design}

Five freshwater mussels were exposed to none $\mathrm{T}_{0}(0 \mu \mathrm{g}$ $\left.\mathrm{L}^{-1}\right)$, low $\mathrm{T}_{1}\left(120 \mu \mathrm{g} \mathrm{L}^{-1}\right)$, medium $\mathrm{T}_{2}\left(240 \mu \mathrm{g} \mathrm{L}^{-1}\right)$ and high $\mathrm{T}_{3}\left(360 \mu \mathrm{g} \mathrm{L}^{-1}\right)$ doses of lead, copper and chromium in glass tanks (24"x18"x24") in triplicate design (3 tanks as per treatment) for 15 days. Primary stock solutions of $\mathrm{Pb}, \mathrm{Cu}$ and $\mathrm{Cr}$ were prepared in distilled water by using $\mathrm{Pb}\left(\mathrm{NO}_{3}\right)$, $\mathrm{Cr}\left(\mathrm{NO}_{3}\right) \cdot 9 \mathrm{H}_{2} \mathrm{O}$ and $\mathrm{CuSO}_{4} .5 \mathrm{H}_{2} \mathrm{O}$, respectively, and further diluted to achieve the required concentration for exposure. The water was changed after every 5 days with the renewal of each chemical. The temperature and $\mathrm{pH}$ of aquarium water was $17.6 \pm 1.3^{\circ} \mathrm{C}$ and $7.15 \pm 0.15$, respectively. The mussels were sacrificed at the end of experiment and gills were collected for estimation of DNA damage.

\section{Isolation of gill cells}

Mussels shells were washed with distilled water to remove the unwanted particles before those were opened with the help of a scalpel and small steel rod. The gills were then excised carefully and rinsed in cold phosphate buffer solution (PBS) under low light to eliminate the risk of UV-induced DNA damage. The isolation of gill cells were carried out by a mechanical process by mincing the chopped gills in a cold PBS with the help of sterilised sharp scalpel blades for $15 \mathrm{~min}$. Then suspension was passed through a $40 \mu \mathrm{m}$ sieve to remove the large particles and the filtrate was diluted in $1 \mathrm{ml}$ PBS. The cell viability in PBS was assessed by using the trypan blue exclusion test and it was $>85 \%$ in all the cases.

\section{Comet assay}

The protocol of comet assay was used according to Singh et al. (1988). Ethidium bromide $(2 \mu \mathrm{g} / \mathrm{ml})$ was used for staining the slide and then examined with fluorescence microscope at magnification power of $x 400$. The scoring of microscopic images was carried out by using computer software Comet IV. Three slides were prepared from each 
sample and the images of 20 cells were scored from each slide. Olive tail moment (product of tail length and the fraction of total DNA in the tail), comet tail length and amount of DNA in comet tail were the parameters assessed for DNA damaging.

\section{Statistical analysis}

Analysis of variance (ANOVA) was applied on data to analyse the variation among comet parameters for different doses of heavy metals. Tukey pairwise comparison test was used to assess the difference between control and treatment groups and statistical significance was defined at $p<0.05$. Minitab 17 software and Microsoft excel were used for all the statistical analysis.

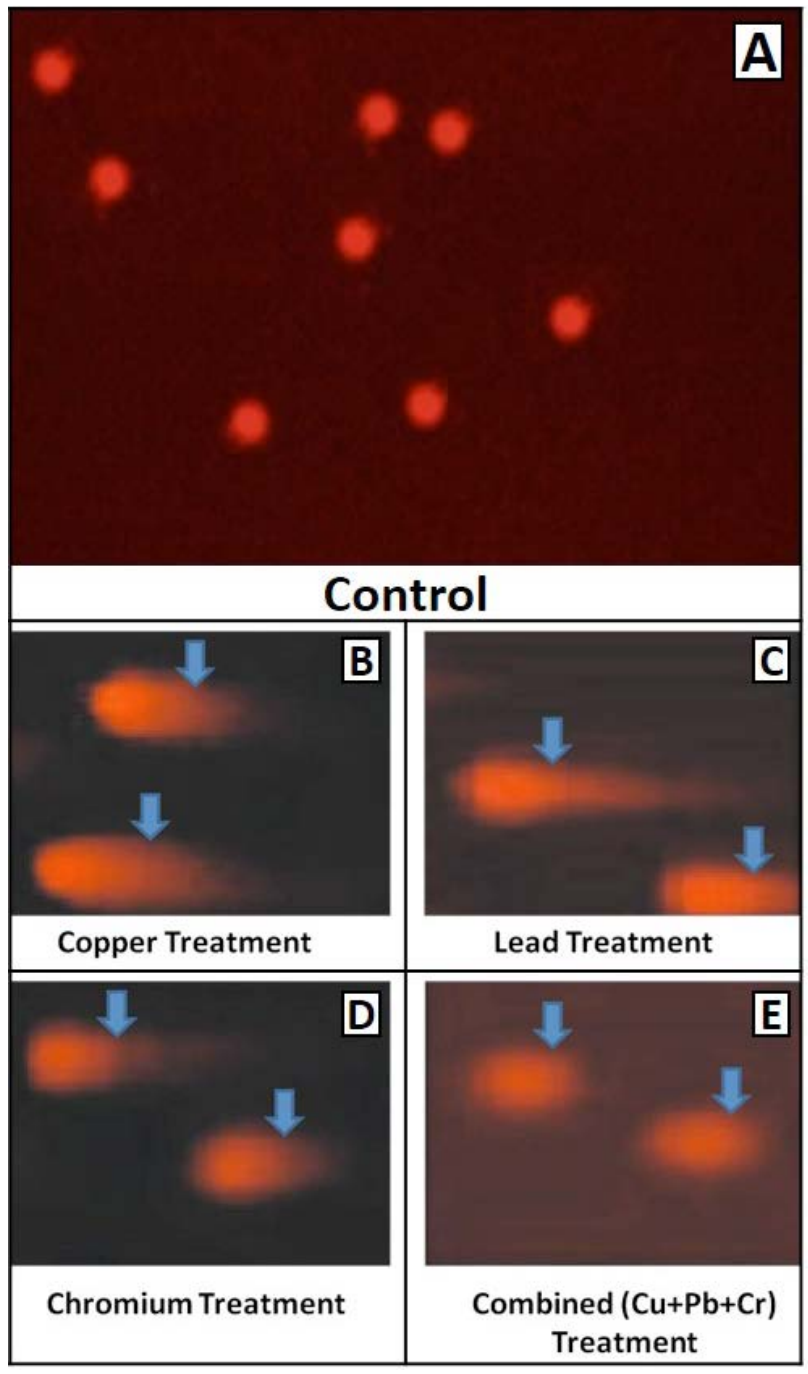

Fig. 1. The image of comets by fluorescent microscope from the gills of freshwater mussels (Anodonta anatina) collected from the control (A) and treated tanks (B to E).

\section{RESULTS}

There were significant differences between treatment groups at all concentration as compared to controls except the combined treatment at low and medium dose and $\mathrm{Cr}$ alone at higher dose (Table I). The control levels were the same for all metals so had same value as mentioned in Table I. The value of tail DNA percentage, tail length and olive tail moment decreased from lower to higher doses of metals but still the values at high doses were significantly higher than the controls except the chromium and combined treatments which returned to the control level. The comet image of gill cells of freshwater mussels collected from the control tank showed no damages in DNA (Fig. 1A) whereas damage was observed in all treatment groups of various heavy metals (Fig. 1B-E).

For \% of tail DNA highest values were observed in $\mathrm{Cu}$-exposed mussels $(56.74 \pm 1.81)$ as compared to $\mathrm{Pb}$ (47.36 \pm 1.23$), \mathrm{Cr}(43.0 \pm 1.31)$ and combined treatment $(25.94 \pm 1.16)$ at low dose $\left(120 \mu \mathrm{g} \mathrm{L}^{-1}\right)$. The least value of tail DNA was noticed at high dose $\left(360 \mu \mathrm{g} \mathrm{L}^{-1}\right)$ such as for $\mathrm{Cu}(20.89 \pm 0.55), \mathrm{Pb}(10.88+0.73), \mathrm{Cr}(7.94 \pm 0.71)$ and combined $(8.16 \pm 0.98)$ treatments. There were no significant differences between the $\mathrm{Pb}$ and $\mathrm{Cr}$ at low concentration $\left(120 \mu \mathrm{g} \mathrm{L}^{-1}\right)$ but both were significantly different from $\mathrm{Cu}$ and combined treatment $(\mathrm{Pb}+\mathrm{Cu}+\mathrm{Cr})$ at the same concentration. The values in combined metal exposure at medium concentration $\left(240 \mu \mathrm{g} \mathrm{L}^{-1}\right)$ was significantly lower than all the other treatments at the same concentration $(\mathrm{p}<0.05)($ Table I).

In case of comet tail length, significantly higher values were observed in $\mathrm{Pb}$-exposed mussels (49.15 \pm 1.90$)$ followed by $\mathrm{Cu}(41.30 \pm 0.75) \quad \mathrm{Cr} \quad(26.6 \pm 0.78)$ and combined treatment $(18.20 \pm 1.13)$ at low dose. Trend for the same parameter in all metals at low dose was $\mathrm{Pb}>$ $\mathrm{Cu}>\mathrm{Cr}>\mathrm{Pb}+\mathrm{Cu}+\mathrm{Cr}$ (Table I). As usual the value of comet tail length was also decreasing with increasing the concentration of metals. The lowest values of tail length were found at higher dose $\left(360 \mu \mathrm{g} \mathrm{L}^{-1}\right)$ of all metals exposure such as $\mathrm{Cu}(16.05 \pm 0.73), \mathrm{Pb}(9.00 \pm 0.67), \mathrm{Cr}(8.30 \pm 0.54)$ and combined-metal exposure (7.20 \pm 0.53$)$ (Table I).

The value of olive tail moment (OTM) also varied among the different doses of metals. $\mathrm{Cu}$ and $\mathrm{Pb}$ exposure showed significantly higher value of OTM $(13.48 \pm 0.44$, $12.91 \pm 0.45$, respectively) at the low doses $(\mathrm{p}<0.05)$ and again the $\mathrm{Cr}$ and combined treatment showed low value $(6.94 \pm 0.38,3.89 \pm 0.20$, respectively) at the same dose. The value of OTM was significantly higher $(7.75 \pm 0.16)$ in $\mathrm{Cu}$ exposure at the medium dose as compared to other metals exposure at the same dose. There were no significant differences found between $\mathrm{Pb}$ and $\mathrm{Cr}$ at medium dose and $\mathrm{Cr}$ and combined metal treatment at the high dose $(\mathrm{p}>0.05)$ 
(Table I). Cr induced low DNA damage than $\mathrm{Cu}$ and $\mathrm{Pb}$ but higher than the combined metal treatment at all the doses for all the parameters (Table I).

Table I.- Effect of different doses of $\mathrm{Pb}, \mathrm{Cu}, \mathrm{Cr}$ individually and in combination on mean \% tail DNA, comet tail length, olive tail moment.

\begin{tabular}{|c|c|c|c|c|}
\hline Dose metals & $\mathbf{T}_{\mathbf{0}}$ & $\mathrm{T}_{1}$ & $\mathbf{T}_{2}$ & $\mathbf{T}_{3}$ \\
\hline \multicolumn{5}{|c|}{ Tail DNA (\%) } \\
\hline $\mathrm{Pb}$ & $\begin{array}{l}1.34 \pm \\
0.28^{g}\end{array}$ & $\begin{array}{c}47.36 \pm \\
1.23^{\mathrm{b}}\end{array}$ & $\begin{array}{c}26.89 \pm \\
0.97^{\mathrm{d}}\end{array}$ & $\begin{array}{c}10.88+ \\
0.73^{\mathrm{f}}\end{array}$ \\
\hline $\mathrm{Cu}$ & $\begin{array}{l}1.34 \pm \\
0.28^{g}\end{array}$ & $\begin{array}{c}56.74 \pm \\
1.81^{\mathrm{a}}\end{array}$ & $\begin{array}{c}30.03 \pm \\
0.42^{\text {cd }}\end{array}$ & $\begin{array}{c}20.89 \pm \\
0.55^{\mathrm{e}}\end{array}$ \\
\hline $\mathrm{Cr}$ & $\begin{array}{l}1.34 \pm \\
0.28^{\mathrm{g}}\end{array}$ & $\begin{array}{c}43.05 \pm \\
1.31^{\mathrm{b}}\end{array}$ & $\begin{array}{c}33.86 \pm \\
1.71^{\mathrm{c}}\end{array}$ & $\begin{array}{l}7.94 \pm \\
0.71^{\mathrm{f}}\end{array}$ \\
\hline $\mathrm{Pb}+\mathrm{Cu}+\mathrm{Cr}$ & $\begin{array}{l}1.34 \pm \\
0.28^{\mathrm{g}}\end{array}$ & $\begin{array}{c}25.94 \pm \\
1.16^{\mathrm{d}}\end{array}$ & $\begin{array}{c}19.60 \pm \\
1.27^{\mathrm{e}}\end{array}$ & $\begin{array}{c}8.16 \pm \\
0.98^{\mathrm{f}}\end{array}$ \\
\hline \multicolumn{5}{|c|}{ Comet Tail length } \\
\hline $\mathrm{Pb}$ & $\begin{array}{l}3.45^{ \pm} \\
0.23^{\mathrm{g}}\end{array}$ & $\begin{array}{c}49.15 \pm \\
1.90^{\mathrm{a}}\end{array}$ & $\begin{array}{c}21.95 \pm \\
0.89^{\mathrm{d}}\end{array}$ & $\begin{array}{l}9.00 \pm \\
0.67^{\mathrm{f}}\end{array}$ \\
\hline $\mathrm{Cu}$ & $\begin{array}{l}3.45^{ \pm} \\
0.23^{\mathrm{g}}\end{array}$ & $\begin{array}{c}41.30 \pm \\
0.75^{\mathrm{b}}\end{array}$ & $\begin{array}{c}18.05 \pm \\
0.58^{\mathrm{de}}\end{array}$ & $\begin{array}{c}16.05^{ \pm} \\
0.73^{\mathrm{e}}\end{array}$ \\
\hline $\mathrm{Cr}$ & $\begin{array}{l}3.45^{ \pm} \\
0.23^{\mathrm{g}}\end{array}$ & $\begin{array}{c}26.65 \pm \\
0.78^{c}\end{array}$ & $\begin{array}{c}17.40 \pm \\
1.16^{\mathrm{e}}\end{array}$ & $\begin{array}{c}8.30 \pm \\
0.54^{\mathrm{f}}\end{array}$ \\
\hline $\mathrm{Pb}+\mathrm{Cu}+\mathrm{Cr}$ & $\begin{array}{l}3.45^{ \pm} \\
0.23^{\mathrm{g}}\end{array}$ & $\begin{array}{c}18.20 \pm \\
1.13^{\mathrm{de}}\end{array}$ & $\begin{array}{c}8.75 \pm \\
0.57^{\mathrm{f}}\end{array}$ & $\begin{array}{l}7.20 \pm \\
0.53^{\mathrm{fg}}\end{array}$ \\
\hline \multicolumn{5}{|c|}{ Oil Tail moment } \\
\hline $\mathrm{Pb}$ & $\begin{array}{c}0.17 \pm \\
0.03^{\mathrm{h}}\end{array}$ & $\begin{array}{c}12.91^{\mathrm{a}} \pm \\
0.45\end{array}$ & $\begin{array}{l}3.87 \pm \\
0.18^{\mathrm{cd}}\end{array}$ & $\begin{array}{c}1.63^{\mathrm{fg}_{ \pm}} \\
0.09\end{array}$ \\
\hline $\mathrm{Cu}$ & $\begin{array}{l}0.17 \pm \\
0.03^{\mathrm{h}}\end{array}$ & $\begin{array}{c}13.48^{\mathrm{a}} \pm \\
0.44\end{array}$ & $\begin{array}{l}7.75 \pm \\
0.16^{\mathrm{b}}\end{array}$ & $\begin{array}{c}3.38^{\mathrm{de}_{ \pm}} \\
0.10\end{array}$ \\
\hline $\mathrm{Cr}$ & $\begin{array}{l}0.17 \pm \\
0.03^{\mathrm{h}}\end{array}$ & $\begin{array}{c}6.94^{\mathrm{b}} \pm \\
0.38\end{array}$ & $\begin{array}{l}4.85 \pm \\
0.41^{\mathrm{c}}\end{array}$ & $\begin{array}{c}1.30^{\mathrm{gh}} \pm \\
0.11\end{array}$ \\
\hline $\mathrm{Pb}+\mathrm{Cu}+\mathrm{Cr}$ & $\begin{array}{c}0.17 \pm \\
0.03^{\text {h }}\end{array}$ & $\begin{array}{c}3.89^{\mathrm{cd}} \pm \\
0.20\end{array}$ & $\begin{array}{l}2.49 \pm \\
0.18^{\text {ef }}\end{array}$ & $\begin{array}{c}1.12^{\mathrm{gh}} \pm \\
0.13\end{array}$ \\
\hline
\end{tabular}

*Any means $( \pm$ S.E.M) in row and column with different superscripts are significantly different $(\mathrm{p}<0.05)$

$\mathrm{T}_{0}$, none $\left(0 \mu \mathrm{g} \mathrm{L}^{-1}\right) ; \mathrm{T}_{1}$, low $\left(120 \mu \mathrm{g} \mathrm{L}^{-1}\right) ; \mathrm{T}_{2}$, medium $\left(240 \mu \mathrm{g} \mathrm{L}^{-1}\right)$ and $\mathrm{T}_{3}$, high $\left(360 \mu \mathrm{g} \mathrm{L}{ }^{-1}\right)$

\section{DISCUSSION}

$\mathrm{Cu}$ and $\mathrm{Pb}$ both induced high DNA damage in gill cells as compared to $\mathrm{Cr}$ and combined exposure of metals. $\mathrm{Pb}$ showed slightly higher value for the tail length than $\mathrm{Cu}$ at low dose as difference in means was $7.85 \pm 1.92$ $(\mathrm{n}=20)$ but in case of $\%$ of tail DNA Cu shows more value than $\mathrm{Pb}$ and mean difference was $9.38 \pm 2.01 \quad(\mathrm{n}=20)$ at the same dose. For the OTM at the same dose the little difference was observed in between $\mathrm{Cu}$ and $\mathrm{Pb}$ but again more values were observed in $\mathrm{Cu}$-exposed mussels and difference in means was $0.92 \pm 0.65(n=20)$. The combined metals exposure induced very low damaging in DNA as showed in all observed parameters. Vincent-Hubert et al. (2011) compared the haemocytes and gills of mussels for comet assay study and concluded that the gills have more sensitivity for the contaminants as compared to the haemocytes.

Our results resemble to previous study where the mussels were exposed to the Nano and ionic forms of copper and significant difference was observed in copper exposed mussel as compared to controls and it was also stated that the higher damage was observed in mussel exposed to ionic form of $\mathrm{Cu}$ (Gomes et al., 2013).

Bolognesi et al. (1999) also showed similar results where the mussels were exposed to different concentrations of $\mathrm{Cu}$ and high levels of DNA damage were observed at low concentration of $\mathrm{Cu}\left(40 \mu \mathrm{g} \mathrm{L}^{-1}\right)$. Al-Subiai et al. (2011) reported the effect of $\mathrm{Cu}$ on marine mussels and suggested that the high dose of $\mathrm{Cu}$ was toxic to animal and $100 \%$ mortality was observed at $100 \mu \mathrm{g} \mathrm{L}^{-1}$ which is contradictory to our results where no mortality was observed in freshwater mussels at any dose of copper. Our finding are in line with a previous study where mussels were exposed to low and high doses of polycyclic aromatic hydrocarbon and higher levels of DNA strands breaks were observed in mussels which were exposed to the low doses of polycyclic aromatic hydrocarbon (Large et al., 2002). Freshwater mussels were exposed to various doses of $\mathrm{Pb}$ to evaluate the genotoxic effects and significantly high DNA strands breaks was observed at low dose $50 \mu \mathrm{g} \mathrm{L} \mathrm{L}^{-1}$ of lead and very little DNA damage was found at high dose of 500 $\mu \mathrm{g} \mathrm{L}^{-1}$ (Black et al., 1996).

$\mathrm{Cr}$ and combined treatments $(\mathrm{Pb}+\mathrm{Cu}+\mathrm{Cr})$ showed the sametrends; the low level of DNA breaks was observed as the doses were increased. The combined exposure of metals showed very low value in DNA damage than the metals individually which showed some synchronized effects of metals. It is unclear why the combined treatment of heavy metal induced low level of DNA damage but one of the previous study also showed the similar results where the mussels were exposed to the a combination of $\mathrm{Cu}, \mathrm{Cd}$ and $\mathrm{Hg}$ and low level of DNA damage were observed in mussels that were exposed to the combination of metals, studied by Bolognesi et al. (1999). Heavy metals have been shown to induce changes in the metabolism of organism and enhanced the reactive oxygen species which generated oxidative stress and induced DNA damage (Gaetke and Chow, 2003). It is previously mentioned that the metals and nanoparticles have direct effect on DNA in 
nucleus and occasionally during cell division which can cause DNA damage (Bhatt and Tripathi, 2011; Singh et al., 2009; Karlsson, 2010).

Many previous studies had been conducted on freshwater and marine mussels to assess the genotoxic effect of heavy metals and found deleterious effects. $\mathrm{Cr}$ is the major industrial discharge that put adverse effects on animal tissues (Wahlberg and Skog, 1965). The large concentration of $\mathrm{Cr}$ was observed in aquatic environment and it can greatly accumulate in tissues of aquatic animals which may cause defects at molecular level (Fatima and Usmani, 2013; Taweel et al., 2011). The sufficient amount of lead also accumulated in aquatic animals even though at minute levels in aquatic environment (Vinodhini and Narayan, 2008; Abdel-Baki et al., 2011). Pb is noxious even in very small concentration because $\mathrm{Pb}$ can mimic other essential elements such as calcium, magnesium and zinc which inflict deleterious effects on enzyme activity (Jennette, 1981) and also prove carcinogenic (Fracasso et al., 2002). The genotoxic effects of $\mathrm{Pb}$ on freshwater mussels were also reported by Black et al. (1996). Emmanouil et al. (2007) reported that the $\mathrm{Cr}$ has more adverse effects and damaged DNA strands at the tissue concentration of $\geq 2.70 \mu \mathrm{g} / \mathrm{g}$ wet weight under laboratory conditions.

$\mathrm{Cr}$ has been significantly correlated with the DNA strand breaks in the mussels collected from the wild (Rank et al., 2005). Many previous studies reported the significantly higher levels of DNA damage in aquatic organism collected from contaminated water with metals (Frenzilli et al., 2001; Nacci et al., 2002; Steinert et al., 1998). This is in accordance with our findings where the DNA damage detected with the Comet assay seem to be correlated with the comparative heavy metal concentrations in the surrounding environment. Al-Subiai et al. (2011) reported the genotoxic effects of $\mathrm{Cu}$ on the DNA strand breaks of bivalve mussels.

Induction of DNA damaging has also been reported in numerous other studies where animals were exposed to different heavy metals such as mercury, cadmium, $\mathrm{Cr}, \mathrm{Cu}$ and $\mathrm{Pb}$ (Hartmann and Speit, 1994; Hayashi et al., 2000). Several previous studies also reported that the $50 \%$ or higher level of DNA strand breaks in cells of aquatic animals including mussels were linked to the different chemicals exposed in laboratory or in polluted environment (Frenzilli et al., 2001, 2004; Regoli et al., 2005; Machella et al., 2006; Gorbi et al., 2008). Heavy metals are harmful for aquatic life and in present study the specific effect of metals at the specific concentrations was evaluated on sub-cellular level of bivalves.

\section{CONCLUSION}

It is concluded that the $\mathrm{Cu}$ and $\mathrm{Pb}$ induced higher levels of DNA damage compared to $\mathrm{Cr}$ and combined metal exposure. Furthermore our findings showed that the low dose $\left(120 \mu \mathrm{g} \mathrm{L}^{-1}\right)$ of metal concentrations had more genotoxic effect compared to the medium $\left(240 \mu \mathrm{g} \mathrm{L}^{-1}\right)$ and high $\left(360 \mu \mathrm{g} \mathrm{L}^{-1}\right)$ doses. Gills are suggested to be the best target organ to assess the genotoxic effects and the freshwater mussels (Anodonta anatina) are considered as one of the key species for bio-monitoring studies.

\section{ACKNOWLEDGMENTS}

This work was funded by Higher Education Commission (HEC) Pakistan under International Research Support Initiative Program (IRSIP) which enabled the first author to attend the Newcastle University, UK.

Statement of conflict of interest

Authors have declared no conflict of interest.

\section{REFERENCES}

Abdel-Baki, A.S., Dkhil, M.A. and Al-Quraishy, S., 2013. Bioaccumulation of some heavy metals in tilapia fish relevant to their concentration in water and sediment of Wadi Hanifah, Saudi Arabia. Afri. J. Biotech., 10: 2541-2547.

Al-Subiai, S.N., Moody, A.J., Mustafa, S.A. and Jha, A.N., 2011. A multiple biomarker approach to investigate the effects of copper on the marine bivalve mollusc, Mytilus edulis. Ecotoxicol. environ. Safe., 74: 1913-1920. https://doi. org/10.1016/j.ecoenv.2011.07.012

Berrahal, A.A., Lasram, M., El, J.N., Kerkeni, A., Gharbi, N. and El-Fazâa, S., 2011. Effect of agedependent exposure to lead on hepatotoxicity and nephrotoxicity in male rats. Environ. Toxicol., 26: 68-78. https://doi.org/10.1002/tox.20530

Bhatt, I. and Tripathi, B.N., 2011. Interaction of engineered nanoparticles with various components of the environment and possible strategies for their risk assessment. Chemosphere, 82: 308-317. https:// doi.org/10.1016/j.chemosphere.2010.10.011

Binelli, A., Cogni, D., Parolini, M. and Provini, A., 2010. Multi-biomarker approach to investigate the state of contamination of the R. Lambro/R. Po confluence (Italy) by zebra mussel (Dreissena polymorpha). Chemosphere, 79: 518-528. https:// doi.org/10.1016/j.chemosphere.2010.02.033

Binelli, A., Riva, C. and Provini, A., 2007. Biomarkers in 
Zebra mussel for monitoring and quality assessment of Lake Maggiore (Italy). Biomarkers, 12: 349-368. https://doi.org/10.1080/13547500701197412

Black, M.C., Ferrell, J.R., Horning, R.C. and Martin, L.K., 1996. DNA strand breakage in freshwater mussels (Anodonta grandis) exposed to lead in the laboratory and field. Environ. toxicol. Chem., 15: 802-808. https://doi.org/10.1002/etc.5620150528

Blackmore, G. and Wang, W.X., 2003. Comparison of metal accumulation in mussels at different local and global scales. Environ. Toxicol. Chem., 22: 388-395. https://doi.org/10.1002/etc.5620220221

Bolognesi, C., Landini, E., Roggieri, P., Fabbri, R. and Viarengo, A., 1999. Genotoxicity biomarkers in the assessment of heavy metal effects in mussels: experimental studies. Environ. Mol. Mutat., 33: 287-292. https://doi.org/10.1002/(SICI)10982280(1999)33:4<287::AID-EM5>3.3.CO;2-7

Bourgeault, A., Gourlay-France, C., Vincent-Hubert, F., Palais, F., Geffard, A., Biagianti-Risbourg, S. and Tusseau-Vuillemin, M.H., 2010. Lessons from a transplantation of zebra mussels into a small urban river: an integrated ecotoxicological assessment. Environ. Toxicol., 25: 468-478. https:// doi.org/10.1002/tox.20591

Cantillo, A.Y., 1998. Comparison of results of mussel watch programs of the United States and France with worldwide mussel watch studies. Mar. Pollut. Bull., 36: 712-717. https://doi.org/10.1016/S0025326X(98)00049-6

Chen, Y., Chen, H., Wu, Y., Li, Z., Sun, L., Qu, M. and Kong, Z., 2007. Toxicity evaluation of Meiliang Bay, Lake Taihu, China a drinking water source. In: Eutrophication of shallow lakes with special reference to Lake Taihu, China. Springer Netherland, pp. 297-303. https://doi.org/10.1007/978-1-40206158-5 30

Depledge, M.H., 1998. The ecotoxicological significance of genotoxicity in marine invertebrates. Mutat. Res., 399: 109-122. https://doi.org/10.1016/S00275107(97)00270-4

Emmanouil, C., Sheehan, T.M.T. and Chipman, J.K., 2007. Macromolecule oxidation and DNA repair in mussel (Mytilus edulis L.) gill following exposure to $\mathrm{Cd}$ and $\mathrm{Cr}$ (VI). Aquat. Toxicol., 82: 27-35. https://doi.org/10.1016/j.aquatox.2007.01.009

Fatima, M. and Usmani, N., 2013. Toxicity and ecological impacts. Pak. J. biol. Sci., 16: 412-420. https://doi.org/10.3923/pjbs.2013.412.420

Fracasso, M.E., Perbellini, L., Solda, S., Talamini, G. and Franceschetti, P., 2002. Lead induced DNA strand breaks in lymphocytes of exposed workers: role of reactive oxygen species and protein kinase $\mathrm{C}$. Mutat. Res., 515: 159-169. https://doi.org/10.1016/ S1383-5718(02)00012-8

Frenzilli, G., Nigro, M., Scarcelli, V., Gorbi, S. and Regoli, F., 2001. DNA integrity and total oxyradical scavenging capacity in the Mediterranean mussel, Mytilus galloprovincialis: a field study in a highly eutrophicated coastal lagoon. Aquat. Toxicol., 53: 19-32. https://doi.org/10.1016/S0166445X(00)00159-4

Frenzilli, G., Scarcelli, V., del Barga, I., Nigro, M., Forlin, L., Bolognesi, C. and Sturve, J., 2004. DNA damage in eelpout (Zoarces viviparus) from Göteborg harbour. Mutat. Res., 552: 187-195. https://doi.org/10.1016/j.mrfmmm.2004.06.018

Gaetke, L.M. and Chow, C.K., 2003. Copper toxicity, oxidative stress, and antioxidant nutrients. Toxicology, 189: 147-163. https://doi.org/10.1016/ S0300-483X(03)00159-8

Goldberg, E.D., 1986. The mussel watch concept. Environ. Monit. Assess., 7: 91-103. https://doi. org/10.1007/BF00398031

Gomes, T., Araujo, O., Pereira, R., Almeida, A.C., Cravo, A. and Bebianno, M.J., 2013. Genotoxicity of copper oxide and silver nanoparticles in the mussel Mytilus galloprovincialis. Mar. environ. Res., 84: 51-59. https://doi.org/10.1016/j. marenvres.2012.11.009

Gorbi, S., Lamberti, C.V., Notti, A., Benedetti, M., Fattorini, D., Moltedo, G. and Regoli, F., 2008. An ecotoxicological protocol with caged mussels, Mytilus galloprovincialis, for monitoring the impact of an offshore platform in the Adriatic sea. Mar. environ. Res., 65: 34-49. https://doi.org/10.1016/j. marenvres.2007.07.006

Hansen, A.M., 2012. Lake sediment cores as indicators of historical metal (loid) accumulation. A case study in Mexico. Appl. Geochem., 27: 1745-1752. https://doi.org/10.1016/j.apgeochem.2012.02.010

Hartmann, A. and Speit, G., 1994. Comparative investigations of the genotoxic effects of metals in the single cell gel (SCG) assay and the sister chromatid exchange (SCE) test. Environ. Mol. Mutat., 23: 299-305. https://doi.org/10.1002/ em. 2850230407

Hayashi, M., Kuge, T., Endoh, D., Nakayama, K., Arikawa, J., Takazawa, A. and Okui, T., 2000. Hepatic copper accumulation induces DNA strand breaks in the liver cells of Long-Evans Cinnamon strain rats. Biochem. biophys. Res. Commun., 276: 174-178. https://doi.org/10.1006/bbrc.2000.3454

Jennette, K.W., 1981. The role of metals in 
carcinogenesis: biochemistry and metabolism. Environ. Hlth Perspec., 40: 233-252. https://doi. org/10.1289/ehp. 8140233

Jha, A.N., 2008. Ecotoxicological applications and significance of the comet assay. Mutagenesis, 23: 207-221. https://doi.org/10.1093/mutage/gen014

Johannesson, M., 2002. A review of risks associated to arsenic, cadmium, lead, mercury and zinc. Kalmar University Sweden, pp. 38-47.

Kalpaxis, D. L., Theos, C., Xaplanteri, M. A., Dinos, G. P., Catsiki, A. V. and Leotsinidis, M., 2004. Biomonitoring of Gulf of Patras, N. Peloponnesus, Greece. Application of a biomarker suite including evaluation of translation efficiency in Mytilus galloprovincialis cells. Environ. Res., 94: 211-220. https://doi.org/10.1016/S0013-9351(03)00048-3

Karlsson, H.L., 2010. The comet assay in nanotoxicology research. Anal. Bioanal. Chem., 398: 651-666. https://doi.org/10.1007/s00216-010-3977-0

Kimbrough, K.L., Lauenstein, G.G., Christensen, J.D. and Apeti, D.A., 2008. An assessment of two decades of contaminant monitoring in the Nation's Coastal Zone.

Klobucar, G.I., Stambuk, A., Hylland, K. and Pavlica, M., 2008. Detection of DNA damage in haemocytes of Mytilus galloprovincialis in the coastal ecosystems of Kaštela and Trogir bays, Croatia. Sci. Total. Environ., 405: 330-337. https://doi.org/10.1016/j. scitotenv.2008.05.015

Large, A.T., Shaw, J.P., Peters, L.D., Mcintosh, A.D., Webster, L., Mally, A. and Chipman, J.K., 2002. Different levels of mussel (Mytilus edulis) DNA strand breaks following chronic field and acute laboratory exposure to polycyclic aromatic hydrocarbons. Mar. Environ. Res., 54: 493-497. https://doi.org/10.1016/S0141-1136(02)00139-3

Machella, N., Battino, M., Pisanelli, B. and Regoli, F., 2006. Influence of the SCGE protocol on the amount of basal DNA damage detected in the Mediterranean mussel, Mytilus galloprovincialis. Environ. Mol. Mutagen., 47: 579-586. https://doi. org/10.1002/em.20231

Makala, P. and Oikari, A. O.J., 1990. Uptake and body distribution of chlorinated phenolic in the freshwater mussel, Anodonta atina L. Ecotoxicol. Environ. Safe., 20: 354-362. https://doi.org/10.1016/01476513(90)90012-T

Nacci, D.E., Kohan, M., Pelletier, M. and George, E., 2002. Effects of benzo [a] pyrene exposure on a fish population resistant to the toxic effects of dioxinlike compounds. Aquat. Toxicol., 57: 203-215. https://doi.org/10.1016/S0166-445X(01)00196-5
Parolini, M., Binelli, A. and Provini, A., 2011. Assessment of the potential cyto-genotoxicity of the nonsteroidal anti-inflammatory drug (NSAID) diclofenac on the zebra mussel (Dreissena polymorpha). Water Air Soil Pollut., 217: 589-601. https://doi.org/10.1007/s11270-010-0612-9

Parry, H.E. and Pipe, R.K., 2004. Interactive effects of temperature and copper on immunocompetence and disease susceptibility in mussels (Mytilus edulis). Aquat. Toxicol., 69: 311-325. https://doi. org/10.1016/j.aquatox.2004.06.003

Picado, A., Bebianno, M.J., Costa, M.H., Ferreira, A. and Vale, C., 2007. Biomarkers: a strategic tool in the assessment of environmental quality of coastal waters. Hydrobiology, 587: 79-87. https://doi. org/10.1007/s10750-007-0695-5

Ra, K., Bang, J.H., Lee, J.M., Kim, K.T. and Kim, E.S., 2011. The extent and historical trend of metal pollution recorded in core sediments from the artificial Lake Shihwa, Korea. Mar. Pollut. Bull., 62: 1814-1821. https://doi.org/10.1016/j. marpolbul.2011.05.010

Rank, J., Jensen, K. and Jespersen, P.H., 2005. Monitoring DNA damage in indigenous blue mussels (Mytilus edulis) sampled from coastal sites in Denmark. Mutat. Res., 585: 33-42. https://doi. org/10.1016/j.mrgentox.2005.04.008

Regoli, F., Gorbi, S., Machella, N., Tedesco, S., Benedetti, M., Bocchetti, R. and Principato, G., 2005. Pro-oxidant effects of extremely low frequency electromagnetic fields in the land snail Helix aspersa. Free Rad. Biol. Med., 39: $\quad 1620-1628 . \quad$ https://doi.org/10.1016/j. freeradbiomed.2005.08.004

Reinecke, A.J., Snyman, R.G. and Nel, J.A.J., 2003. Uptake and distribution of lead $(\mathrm{Pb})$ and cadmium (Cd) in the freshwater crab, Potamonautes perlatus (Crustacea) in the Eerste River, South Africa. Water Air Soil Pollut., 145: 395-408. https://doi. org/10.1023/A:1023602121272

Rocher, B., Le Goff, J., Peluhet, L., Briand, M., Manduzio, H., Gallois, J. and Cachot, J., 2006. Genotoxicant accumulation and cellular defence activation in bivalves chronically exposed to waterborne contaminants from the Seine River. Aquat. Toxicol., 79: 65-77. https://doi.org/10.1016/j. aquatox.2006.05.005

Sarkar, S. K., Cabral, H., Chatterjee, M., Cardoso, I., Bhattacharya, A. K., Satpathy, K. K. and Alam, M. A., 2008. Biomonitoring of heavy metals using the bivalve molluscs in Sunderban mangrove wetland, northeast coast of Bay of Bengal (India): possible 
risks to human health. Clean Soil. Air. Water, 36: 187-194. https://doi.org/10.1002/clen.200700027

Singh, N.P., Mccoy, M.T., Tice, R.R. and Schneider, E.L., 1988. A simple technique for quantitation of low levels of DNA damage in individual cells. Exp. Cell Res., 175: 184-191. https://doi. org/10.1016/0014-4827(88)90265-0

Singh, N., Manshian, B., Jenkins, G.J., Griffiths, S.M., Williams, P.M., Maffeis, T.G. and Doak, S.H., 2009. NanoGenotoxicology: the DNA damaging potential of engineered nanomaterials. Biomaterials, 30: 3891-3914. https://doi. org/10.1016/j.biomaterials.2009.04.009

Soegianto, A., Charmantier-Daures, M., Trilles, J.P. and Charmantier, G., 1999. Impact of copper on the structure ofgills andepipodites of the shrimpPenaeus japonicus (Decapoda). J. Crust. Biol., 19: 209-223. https://doi.org/10.1163/193724099X00015

Sohail, M., Qureshi, N.A., Khan, N., Khan, M.N., Iqbal, K.J. and Abbas, F., 2014. Effect of supplementary feed, fertilizer, and physico-chemical parameters on pond productivity stocked with Indian major carps in monoculture system. Pakistan J. Zool., 46: 1633-1639.

Stambuk, A., Pavlica, M., Malovic, L. and Klobucsar, G.I., 2008. Persistence of DNA damage in the freshwater mussel Unio pictorum upon exposure to ethyl methanesulphonate and hydrogen peroxide. Environ. Mol. Mutagen., 49: 217-225. https://doi. org/10.1002/em.20376

Steinert, S.A., Streib-Montee, R., Leather, J.M. and Chadwick, D.B., 1998. DNA damage in mussels at sites in San Diego Bay. Mutat. Res., 399: 65-85. https://doi.org/10.1016/S0027-5107(97)00267-4

Taweel, A., Shuhaimi-Othman, M. and Ahmad, A.K., 2011. Heavy metals concentration in different organs of tilapia fish(Oreochromis niloticus) from selected areas of Bangi, Selangor, Malaysia. Afri. J. Biotech., 10: 11562-11566.

Thevenon, F., de Alencastro, L.F., Loizeau, J.L., Adatte, T., Grandjean, D., Wildi, W. and Pote, J., 2013. A high-resolution historical sediment record of nutrients, trace elements and organochlorines (DDT and PCB) deposition in a drinking water reservoir (Lake Brêt, Switzerland) points at local and regional pollutant sources. Chemosphere,
90: 2444-2452. https://doi.org/10.1016/j. chemosphere.2012.11.002

Tsangaris, C., Kormas, K., Strogyloudi, E., Hatzianestis, I., Neofitou, C., Andral, B. and Galgani, F., 2010. Multiple biomarkers of pollution effects in caged mussels on the Greek coastline. Comp. Biochem. Physiol. Part C: Toxicol. Pharmacol., 151: 369378. https://doi.org/10.1016/j.cbpc.2009.12.009

Turkmen, M., Turkmen, A., Tepe, Y., Ates, A. and Gokkus, K., 2008. Determination of metal contaminations in sea foods from Marmara, Aegean and Mediterranean seas: Twelve fish species. $F d$. Chem., 108: 794-800. https://doi.org/10.1016/j. foodchem.2007.11.025

United Nations Environment Programme (UNEP), 2011. Annual Report 2010. A Year in Review. United Nations Environment Programme, Nairobi.

Viarengo, A. and Canesi, L., 1991. Mussels as biological indicators of pollution. Aquaculture, 94: 225-243. https://doi.org/10.1016/0044-8486(91)90120-V

Vincent-Hubert, F., Arini, A. and Gourlay-France, C., 2011. Early genotoxic effects in gill cells and haemocytes of Dreissena polymorpha exposed to cadmium, B [a] $\mathrm{P}$ and a combination of $\mathrm{B}$ [a] $\mathrm{P}$ and Cd. Mutat. Res., 723: 26-35. https://doi. org/10.1016/j.mrgentox.2011.03.008

Vinodhini, R. and Narayanan, M., 2008. Bioaccumulation of heavy metals in organs of fresh water fish Cyprinus carpio (Common carp). Int. J. environ. Sci. Tech., 5: 179-182.

Wahlberg, J.E. and Skog, E., 1965. Percutaneous absorption of trivalent and hexavalent chromium: a comparative investigation in the guinea pig by means of 51Cr. Arch. Dermatol., 92: 315-318. https://doi.org/10.1001/archderm.92.3.315

Zan, F., Huo, S., Xi, B., Zhu, C., Liao, H., Zhang, J. and Yeager, K.M., 2012. A 100-year sedimentary record of natural and anthropogenic impacts on a shallow eutrophic lake, Lake Chaohu, China. J. Environ. Monit., 14: 804-816. https://doi.org/10.1039/ c1em10760g

Zhou, Q., Zhang, J., Fu, J., Shi, J. and Jiang, G., 2008. Biomonitoring: an appealing tool for assessment of metal pollution in the aquatic ecosystem. Anal. Chim. Acta, 606: 135-150. https://doi.org/10.1016/j. aca.2007.11.018 